\title{
Performance Evaluation of Cup-Anemometers and Wind Speed Characteristics Analysis
}

\author{
M. A. Baseer ${ }^{1,2}$, J. P. Meyer ${ }^{1}$, S. Rehman ${ }^{3 . *}$, Md. M. Alam ${ }^{4}$, L. M. Al-Hadhrami ${ }^{3}$ \\ ${ }^{1}$ Mechanical and Aeronautical Engineering Department, University of Pretoria, Pretoria, South \\ Africa \\ ${ }^{2}$ Department of Mechanical \& Manufacturing Engineering Technology, Jubail Industrial \\ College, Jubail, Saudi Arabia \\ E-mail: abaseer77@yahoo.com \\ Iosua.Meyer@up.ac.za \\ ${ }^{3}$ Center for Engineering Research, Research Institute, King Fahd University of Petroleum and \\ Minerals, Dhahran-31261, Saudi Arabia \\ E-mail: srehman@kfupm.edu.sa \\ luaimalh@kfupm.edu.sa \\ ${ }^{4}$ Shenzhen Graduate School, Harbin Institute of Technology, Shenzhen, China \\ E-mail: alamm28@yahoo.com \\ *Corresponding author
}

\begin{abstract}
The objective of the present work is to study the performance of cup-anemometers installed at different heights on a 40meter tall wind mast over an approximate period of 55 months between September 13, 2005 and May 09, 2010. The performance of co-located cup anemometers has been analyzed by calculating the tower distortion factor (TDF), scatter factor (SCF), and developing linear correlations between the co-located sensors. The study showed that the performance of sensors did not deteriorate much with time but slightly higher values of TDF were obtained with passage of time. The SCF values were found to be increasing with decreasing height of wind speed measurements. Finally, a total of 16 wind turbines of $2 \mathrm{MW}$ rated capacity each were used to find the most suitable wind turbine for the location under investigation.
\end{abstract}

Keywords: Tower distortion factor; scatter factor; wind speed; wind anemometer; turbulence intensity; wind power density 


\section{Introduction}

In this modern era of fast technological development and energy intensive life styles, the energy requirements are increasing on global, regional and national levels. Beside regular means of power production to meet these energy demands, new and renewable sources are being encouraged to supplement these requirements. Utilization of renewable sources of energy has two fold benefit, one it reduces the dependence on fossil fuels which means reduction in greenhouse gases (GHG) emissions and two to supply energy where there is no national or regional electrical grid. The fast developing and widely used sources of clean energy include the wind, solar thermal, solar photovoltaic (PV), hydro, geothermal, and biomass. Of these sources, wind energy has been adapted globally due to its availability, commercial acceptability, ease and low cost of operation and maintenance. It is evident from the fact that the annual cumulative wind power installed capacity reached $318.1 \mathrm{GW}$ in 2013 compared to $282.587 \mathrm{GW}$ in 2012 , an increase of $12.56 \%$, Ref. [1]. With cumulative installed capacity of $91.412 \mathrm{GW}$, China remained the leader in wind power industry as of end of 2013. United States of America, Germany, Spain and India remained at $2^{\text {nd }}, 3^{\text {rd }}, 4^{\text {th }}$, and $5^{\text {th }}$ place with total wind power installed capacities of 61.091 GW, $34.25 \mathrm{GW}, 22.959 \mathrm{GW}$, and $20.150 \mathrm{GW}$; respectively by the end of 2013 . With respect to new additions, China remained on top with $16.088 \mathrm{GW}$ and Germany at second place with $3.238 \mathrm{GW}$. However, UK, India, Canada, and USA remained at $3^{\text {rd }}, 4^{\text {th }}, 5^{\text {th }}$ and $6^{\text {th }}$, with new additional capacities of $1.883 \mathrm{GW}, 1.729 \mathrm{GW}, 1.599 \mathrm{GW}$ and $1.084 \mathrm{GW}$; respectively.

Saudi Arabia has always been keen to develop and utilize renewable sources of energy and recently issued a white paper to build a $54 \mathrm{GW}$ renewable energy mix portfolio by 2032 , Ref. [2]. Proposed renewable energy portfolio will include wind, solar, geothermal, and waste to energy resources. Thus, it becomes necessary to conduct energy resource assessment and cost of energy generation of different sources. As way forward, for wind power resource assessment, 40 
$\mathrm{m}$ tall wind masts are being used to measure wind speed at different heights for many years. Recently, seven more $92 \mathrm{~m}$ tall towers have been installed to measure wind speed and direction up to 92 meter height and other meteorological parameters near ground level.

Based on long-term annual average wind speed of more than $4 \mathrm{~m} / \mathrm{s}$, Al-Wejh, Dhahran, Guriat, Turaif, and Yanbo were placed in the preferred category for wind power development Rehman [3] while Al-Jouf, Arar, and Qaisumah with annual average wind speed of $3.75 \mathrm{~m} / \mathrm{s}$ in the second list of preferred locations; Rehman et al. [4]. At most of the locations in Saudi Arabia, wind power can be generated with plant capacity factor of 25 to $35 \%$ (Rehman [4]). According to a recent study based on wind measurements at different heights, Rehman et al. [5] reported that Dhulom, Arar, Juaymah, Rawdat Ben-Habbas, and Dhahran are the promising sites for wind power development in Saudi Arabia. In an earlier study, Rehman et al. [6] conducted a detailed design of a $20 \mathrm{MW}$ grid connected wind farm in the Eastern region of Saudi Arabia and reported that the said wind farm could produce 59,037 MWh of electricity annually with a capacity factor of $33.7 \%$, excluding the losses.

Fagbenle et al. [7] assessed the wind energy potential of Maiduguri and Potiskum, Nigeria using 21 years monthly mean wind data at $10 \mathrm{~m}$ height and found that Maiduguri was better site for standalone and medium scale wind power development. McIntyre et al. [8] estimated the wind potential of Guelph city in Ontario, Canada and concluded that an array of utility-scale turbines could potentially generate $29 \%$ of Guelph's 2005 total electricity demand, whereas one consisting of small-scale turbines could achieve $10 \%$ of that demand. Nor et al. [9] conducted techno-economic wind resource assessment in equatorial regions of Malaysia and concluded that there exist harness able sites for wind power deployment. Based on long-term (1945-1990) wind data from 19 meteorological stations and wind measurements at the sites, Katinas et al. [10] 
reported that the $10 \mathrm{~km}$ wide coastal strip near the Baltic Sea was the most suitable region for large scale wind farm development. Nordman [11] reported that around $29 \%$ of Kenya's tea factories could utilize the wind power potential to meet their power requirements. Weekes et al. [12] investigated a measure-correlate-predict (MCP) approach based on the bivariate Weibull (BW) probability distribution of wind speeds at pairs of correlated sites. Using the artificial wind data, the BW approach outperformed the regression approaches for all measurement periods. When applied to the real wind speed observations however, the performance of the BW approach was comparable to the regression approaches when using a full 12 month measurement period and generally worse than the regression approaches for shorter data periods.

The present study aims at understanding the effect of wind tower shading, aging of wind anemometers on wind measurements and lastly the variation of mean turbulence intensities at the wind measurement site. The other goal is to suggest a suitable and efficient wind turbine of multi-megawatt size for future utilization and deployment. Such studies have become necessary in Saudi Arabian context as it is going ahead to add renewable sources of energy to supplement its power sector. Furthermore, King Abdullah City for Atomic and Renewable Energy (K.A.CARE)'s projections envision a total of $23,900 \mathrm{MW}$ capacity of renewable power by 2020 , increasing to $54,100 \mathrm{MW}$ by 2032 has become a source of inspiration for scientists and engineers to enhance research efforts in different areas of renewable energy, Ref. [2].

\section{Problem Definition}

Wind power resource assessment is the key for effective and efficient wind power realization. Accurate wind resource assessment fully depends on the accuracy of the wind measurements. Wind measurements, though seems to be perfect, but are affected by various inherent factors such as tower shading, sensor aging, power fluctuation, and dust accumulation. 
Of these, power fluctuation and dust accumulation effects are taken care by continuous monitoring and maintenance of the sensors but aging and shading effects need to be analyzed and taken care while conducting resource assessment. The local wind field is changed by the tower supporting an anemometer and also affects the readings of the anemometers. The impact of the tower on wind speed is most pronounced within the tower wake. The top mounted wind anemometers are least suffered from flow distortion caused by the tower and the protruded booms and hence provide the most accurate measurements, Lindelöw et al. [13]. However, in practice it has become necessary to make measurements at lower heights for better wind shear information. This is carried out by installing sensors on booms protruding from the tower. According to the IEC standard the influence on the wind speed measurement from the flow distortion induced by the tower must be kept below $1 \%$ and the influence from the boom should be below 0.5\%, IEC-61400-12-1 [14]. Filippelli and Mackiewicz [15] reported larger measurements deviations of cup anemometers mounted on tubular towers. Canadillas et al. [16] and Canadillas et al. [17] carried out inter comparison between Lidar and conventional mastbased instruments, such as cup/sonic and vanes and found good agreement between the two data sets with high correlation of 0.99 . Westerhellweg et al. [18] reported wind direction dependent turbulence intensity at Fino1 station. However, the data from Fino3 station did not show such a distinct direction dependency.

Saudi Arabia is a vast country with total land area of $2,149,690 \mathrm{~km}^{2}$ and lies between latitudes $31^{\circ} \mathrm{N}$ and $17.5^{\circ} \mathrm{N}$ and longitudes $50^{\circ} \mathrm{E}$ and $36.6^{\circ} \mathrm{E}$. The land elevation varies between 0 and 2,600 $\mathrm{m}$ above the mean sea level (AMSL). Complex terrain is found in the southwest region of the Kingdom. The east and the west coasts of the Kingdom are located on the Arabian Gulf and Red Sea, respectively. Mainly two seasons, winter and summer, are observed during the 
year. Due all these factors, it is difficult and economically infeasible to extend electric grid to all dwellings and communities spread over entire Saudi Arabian land. More over in Saudi Arabia, the per capita energy consumption has reached to $20 \mathrm{kWh} /$ day in 2008 compared to 19.4 $\mathrm{kWh} /$ day in 2007 i.e. a net increase of 3.1\% in just one year (Annual Report MOWE, 2008 [19]). A maximum of $10 \%$ increase in per capita energy was observed in year 2004 compared to that in 2003. On an average over 25 years period from 1984 till 2008, 4.1\% annual increase in per capita energy per day has been observed, Ref. [19] which is really significant and needs to be addressed immediately. The overall increase in the generation capacity during the period $2004-2011$ was $67.6 \%$. The overall load growth during that period $(2004-2011)$ was $73.7 \%$, the growth in the load was the highest during the year $2006-2007$ at $11.9 \%$, followed by $10.8 \%$ during the year 2009 - 2010, Ref. [20].

\section{Wind Measurement Description}

The meteorological sensors including wind speed, wind direction, ambient temperature, relative humidity, barometric pressure and global solar radiation were acquired from NRG, USA and installed at a power plant site in Rawdat Ben Habbas (Latitude $=29^{\circ} 8^{\prime} 00^{\prime \prime} \mathrm{N}$, Longitude $=$ $44^{\circ} 20^{\prime} 00^{\prime \prime} \mathrm{E}$, Altitude $=443 \mathrm{~m}$ ), Saudi Arabia. The physical location of the wind mast is shown in Fig. 1. The technical specifications and working ranges of all the sensors are provided in Table 1. The data collection site at Rawdat Ben Habbas is an open area from all directions except a couple of warehouses and workshop sheds. Data were recorded every 10 minutes on a removable data storage card. The wind speed data were measured at 20,30, and 40 meters height above the ground. At 20,30 and 40 meter heights two sensors were installed and recorded data were tagged as WS1 \& WS2 at 20 meters, WS3 \& WS4 at 30 meters, and WS5 \& WS6 at 40 meters. The 
wind direction was recorded at 30 and 40 meters as WD1 and WD2. A schematic diagram showing the positions of all the sensors on the mast is shown in Fig. 2 and the actual wind mast in Fig. 3. The air temperature $\left({ }^{\circ} \mathrm{C}\right)$ and global solar radiation $\left(\mathrm{W} / \mathrm{m}^{2}\right)$ data were also measured at 2 meters above the ground surface.

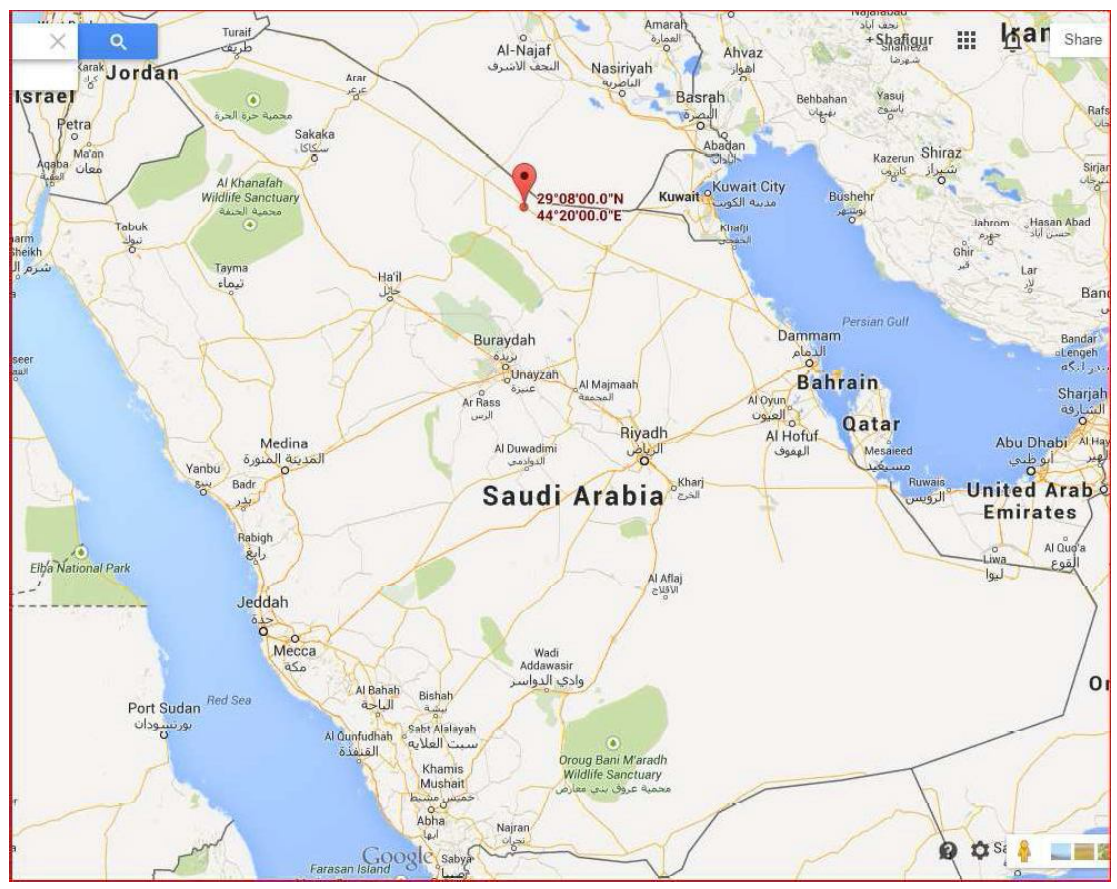

Fig. 1. The location of the measurement station in Rawdat Ben Habbas.

\section{Table 1}

Details of the equipment installed at Rawdat Ben Habbas

\begin{tabular}{|c|c|c|}
\hline S. No. & Item Description & Technical Information \\
\hline 1. & $\begin{array}{l}\text { Symphonie Internet Enabled data } \\
\text { logger }\end{array}$ & $\begin{array}{l}12 \text { Channel, memory and remote data transfer } \\
\text { facility, Symphonie GSM iPack kit }\end{array}$ \\
\hline 2. & Wind speed sensor. NRG $\# 40$ & Type: AC sine wave \\
\hline & Three cup anemometer & $\begin{array}{l}\text { Accuracy: } 0.1 \mathrm{~m} / \mathrm{s} \text { Range: } 1-96 \mathrm{~m} / \mathrm{s} \\
\text { Output: } 0-125 \mathrm{HZ} \text { Threshold: } 0.78 \mathrm{~m} / \mathrm{s}\end{array}$ \\
\hline 3. & Wind direction vane, NRG\#200P & $\begin{array}{l}\text { Type: Potentiometer } \\
\text { Accuracy: } 1 \% \text { Range: } 360^{\circ} \text { Mechanical } \\
\text { Output: } 0 \text {-Exc. Voltage Threshold: } 1 \mathrm{~m} / \mathrm{s} \\
\text { Dead band: Max }-8^{\circ} \text { and Typical } 4^{\circ}\end{array}$ \\
\hline 4. & Temperature sensor $\# 110 \mathrm{~S}$ & $\begin{array}{l}\text { Type: Integrated circuit } \\
\text { Accuracy: } \pm 1.1^{\circ} \mathrm{C} \text { Range: }-40^{\circ} \mathrm{C} \text { to } 52.5^{\circ} \mathrm{C} \\
\text { Output: } 0-2.5 \text { volts DC } \\
\text { Operating temperature range: }-40^{\circ} \mathrm{C} \text { to } 52.5^{\circ} \mathrm{C}\end{array}$ \\
\hline 5. & Pyranometer Li-Cor \#LI-200SA & $\begin{array}{l}\text { Type: Global solar radiation } \\
\text { Accuracy: } 1 \% \text { Range: } 0-3000 \mathrm{~W} / \mathrm{m}^{2} \\
\text { Output: Voltage DC } \\
\text { Operating temperature range: }-40^{\circ} \mathrm{C} \text { to } 65^{\circ} \mathrm{C}\end{array}$ \\
\hline
\end{tabular}




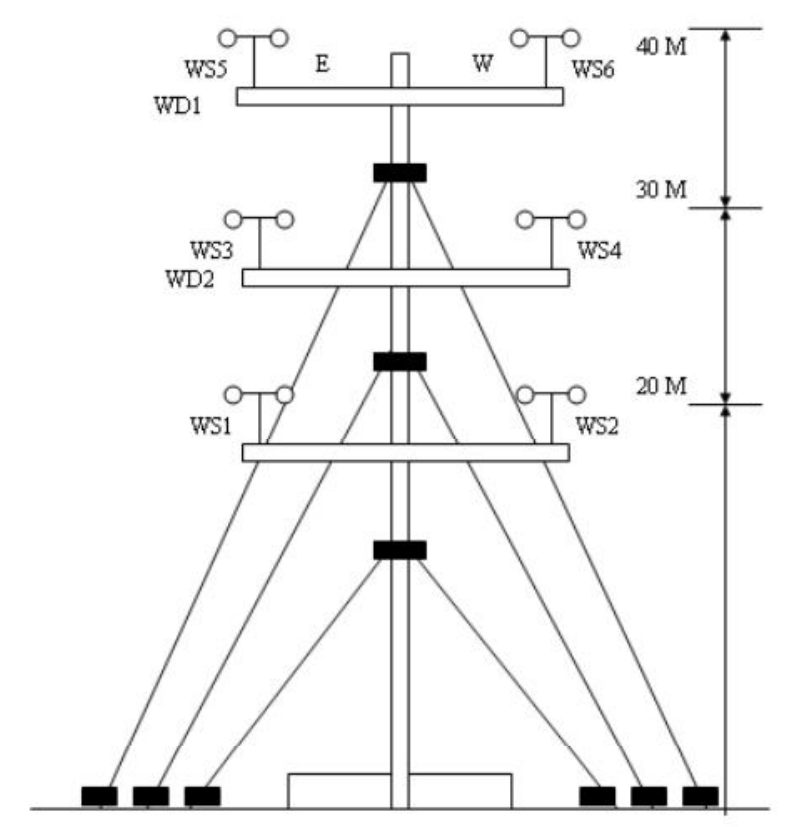

Fig. 2. Schematic diagram of placement of wind speed (WS) and wind direction (WD) sensors on 40 meters tall wind mast.

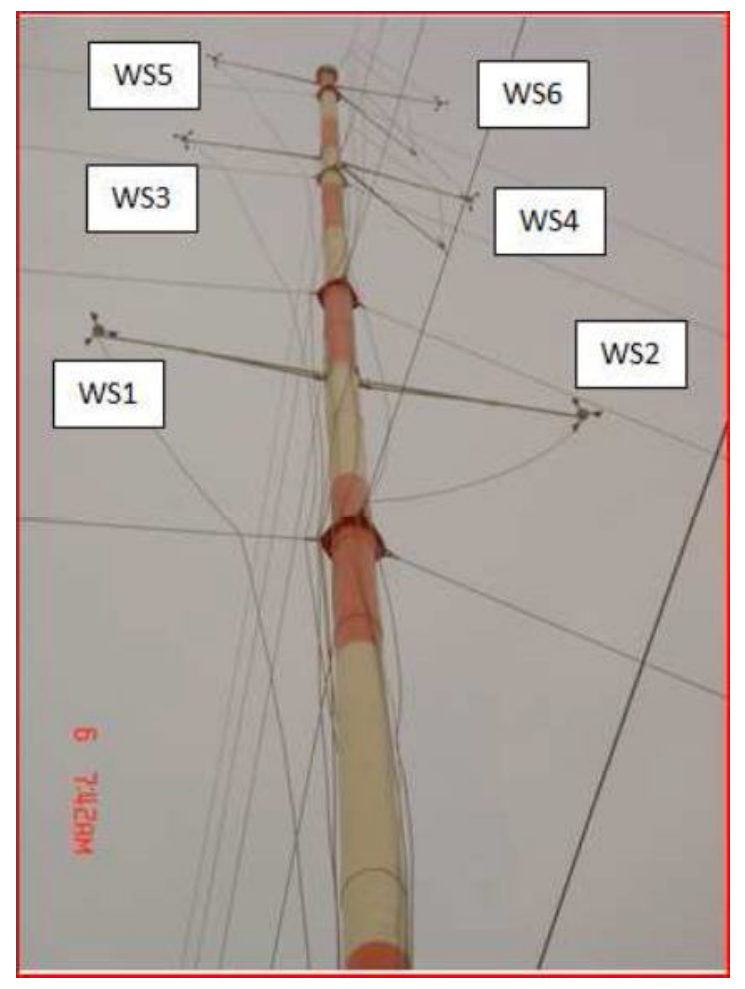

Fig. 3. Erected wind tower at Rawdat Ben Habbas site 


\section{Tower Distortion Factor (TDF) Estimation}

Tower distortion refers to the change in the airflow caused by the presence of the meteorological tower on which the wind speed sensors are mounted. To detect and to minimize the worst effects of tower distortion, wind resource assessment is carried out by installing two wind speed sensors at each measurement height.

The tower distortion factor is the mean of the median ratios in each direction sector. A tower distortion factor of zero means that the sensors are always measuring the same wind speed in each sector. The larger the value of TDF means more overall difference between the readings of the two sensors. The TDF is calculated by finding the ratio of the two wind speeds in each time step, then binning those ratios by direction sector, finding their median value in each bin, and finally calculating the weighted mean of the departure of those median values from unity. The following equation defines the TDF, [21 and 22]:

$$
T D F=\frac{\sum_{i=1}^{n}\left|1-\eta_{i}\right| m_{i}}{\sum_{i=1}^{n} m_{i}}
$$

Where $\mathrm{n}$ is the number of wind director sectors which is taken as 72 in the present case, $\eta_{i}$ is the median value of the ratios of wind speeds in direction sector $\mathrm{i}$, and $m_{i}$ is the number of records in direction sector $i$. The TDF's are calculated using equation 1 in Windographer Software [22] for data sets with tower shading and no tower shading and are summarized in Table 2. For entire data set the number of valid records with no shading were 213,250 and with shading 244,709 i.e. a difference of 31,459 records between the two. For wind speed ratio WS5/WS6 at 40m, the TDF's were 0.003 and 0.014 with no tower shading (NTS) and with tower shading (WTS) respectively. At 30m, TDF' were slightly higher (0.005-NTS and 0.017-WTS) 
than those at $40 \mathrm{~m}$ which simply means that tower shadow effect was more pronounced at $30 \mathrm{~m}$ than at $40 \mathrm{~m}$. Furthermore at $20 \mathrm{~m}$, TDF values were 0.010 (NTS) and 0.021 (WTS), further higher than at $30 \mathrm{~m}$. The TDF's were also calculated for data points excluding the tower shading effect and the invalid data points and these values were found to be $0.003,0.005$, and 0.009 at 40,30 , and $20 \mathrm{~m} \mathrm{AGL;} \mathrm{respectively.} \mathrm{In} \mathrm{general,} \mathrm{higher} \mathrm{values} \mathrm{of} \mathrm{TDF's} \mathrm{were} \mathrm{found} \mathrm{at} \mathrm{lower}$ measurement heights and a decreasing trend with increasing height. This was true for all the data sets considered in the present case i.e. data set with tower shading + invalid records, data set without tower shading + invalid records, and only valid records excluding the tower shading and the invalid records.

With passage of time, the values of TDF's were seen to be increasing, as can be seen from Table 2 from year 2006 to 2008 under both with tower shading (WTS) and no tower shading (NTS) scenarios and at all heights. However the magnitude of change in TDF values was small in case of NTS and only valid records compared to WTS. The magnitude of TDF values in case of NTS and valid records at $40 \mathrm{~m}$ is of the order of 0.005 which is indicative of almost no deterioration of anemometers at this height. At $30 \mathrm{~m}$ and $20 \mathrm{~m}$ heights, the values of TDF were found a bit higher and also increased with year. This is an indication of possible adverse effect of dust and surface roughness on the performance of anemometers at these heights.

Table 2

Tower distortion factors with and without tower shading at Rawdat Ben Habbas wind mast site.

\begin{tabular}{|c|c|c|c|c|c|c|c|c|c|c|c|}
\hline \multirow{3}{*}{ Year } & \multicolumn{9}{|c|}{ Tower Distortion Factor } & \multicolumn{2}{|c|}{ Records } \\
\hline & \multicolumn{3}{|c|}{$\begin{array}{l}\text { With Tower Shading } \\
\text { +Invalids }\end{array}$} & \multicolumn{3}{|c|}{$\begin{array}{l}\text { No Tower Shading } \\
\text { +Invalids }\end{array}$} & \multicolumn{3}{|c|}{$\begin{array}{c}\text { Only Valid Records } \\
\text { No Tower Shading + No } \\
\text { Invalids }\end{array}$} & \multicolumn{2}{|c|}{ Shading } \\
\hline & $40 \mathrm{~m}$ & $30 \mathrm{~m}$ & $20 \mathrm{~m}$ & $40 \mathrm{~m}$ & $30 \mathrm{~m}$ & $20 \mathrm{~m}$ & $40 \mathrm{~m}$ & $30 \mathrm{~m}$ & $20 \mathrm{~m}$ & Yes & No \\
\hline All & 0.014 & 0.017 & 0.021 & 0.003 & 0.005 & 0.010 & 0.003 & 0.005 & 0.009 & 244,709 & 213,250 \\
\hline 2006 & 0.017 & 0.019 & 0.018 & 0.008 & 0.009 & 0.008 & 0.008 & 0.009 & 0.008 & 52,559 & 45,817 \\
\hline 2007 & 0.016 & 0.039 & 0.021 & 0.002 & 0.022 & 0.010 & 0.002 & 0.022 & 0.009 & 52,560 & 46,147 \\
\hline 2008 & 0.023 & 0.023 & 0.039 & 0.009 & 0.010 & 0.036 & 0.009 & 0.010 & 0.032 & 52,704 & 46,675 \\
\hline 2009 & 0.021 & 0.029 & 0.030 & 0.007 & 0.018 & 0.021 & 0.007 & 0.018 & 0.011 & 52,560 & 46,143 \\
\hline
\end{tabular}


The monthly changes in TDF values at different heights are shown in Fig. 4 for entire data set. As seen from this figure, an increasing trend was observed from January till August and then decreasing towards end of the year. Significantly higher values of TDF were found during August till November at 20 and $30 \mathrm{~m}$. The highest value of 0.036 and 0.032 were observed in August at 30 and $20 \mathrm{~m}$, respectively. On the contrary, the minimum values of TDF of 0.010 , 0.014 , and 0.016 were observed in the months of July, December and January at 40,30 , and $20 \mathrm{~m}$ heights; respectively.

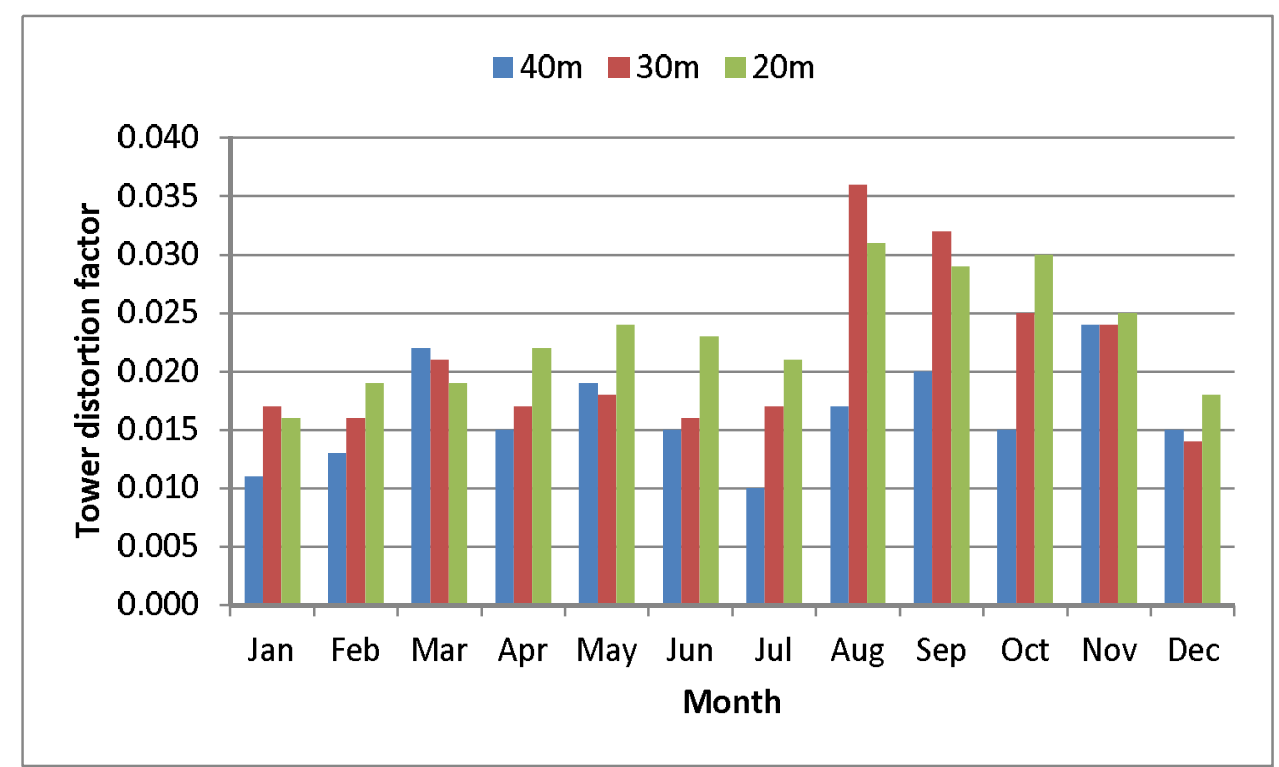

Fig. 4. Monthly variation of tower distortion factor at Rawdat Ben Habbas wind mast site

For visual inspection of the tower shading patterns, two displays are used in the present case. To create these graphs, first the ratio of the wind speeds for each time step was calculated and then for the median ratio graph, the methodology sorted the ratios into 72 direction sector bins and obtained the median ratio in each sector bin. The tower distortion equation is based on median ratio values rather than mean ratio values because median values are less influenced by outliers. Wind data sets can include many erroneous values, which can lead to many spurious 
outliers in wind speed ratios. The highest and lowest values of the median ratios indicate the shaded sectors which are affected by the tower shading phenomenon.

At 40m above ground level, the tower shading effect on wind speeds WS5 and WS6 for entire data set is shown in Fig. 5. In case of WS5 the tower shading effect was pronounced $(>1)$ within wind direction range of WD2 from $205^{\circ}$ to $235^{\circ}$ as shown in Fig. 5. In case of WS6, the tower shading effect $(<1)$ was evident from WD2 of $20^{\circ}$ to $50^{\circ}$. These tower shading effects on WS5 and WS6 are also shown by scatter diagram of wind speed ratios versus wind direction WD2 in Fig. 5.

In case of WS3 at 30m, the tower shading effect was evident $(>1)$ within wind direction range WD1 from $195^{\circ}$ to $225^{\circ}$ as shown in Fig. 6. In case of WS4, the tower shading effect $(<1)$ was evident from WD1 of $20^{\circ}$ to $50^{\circ}$. These tower shading effects on WS3 and WS4 are also shown by scatter diagram of wind speed ratios versus wind direction WD1 in Fig. 6. In case of WS1 the tower shading effect was higher $(>1)$ within wind direction range of $200^{\circ}$ to $230^{\circ}$ as shown in Fig. 7. In case of WS2, the tower shading effect $(<1)$ was evident from WD1 of $30^{\circ}$ to $60^{\circ}$. These tower shading effects on WS1 and WS2 are also shown by scatter diagram of wind speed ratios versus wind direction WD1 in Fig. 7. The corrective measures can be taken by flagging the values of wind speed lying in the wind directions ranges as mentioned earlier. 


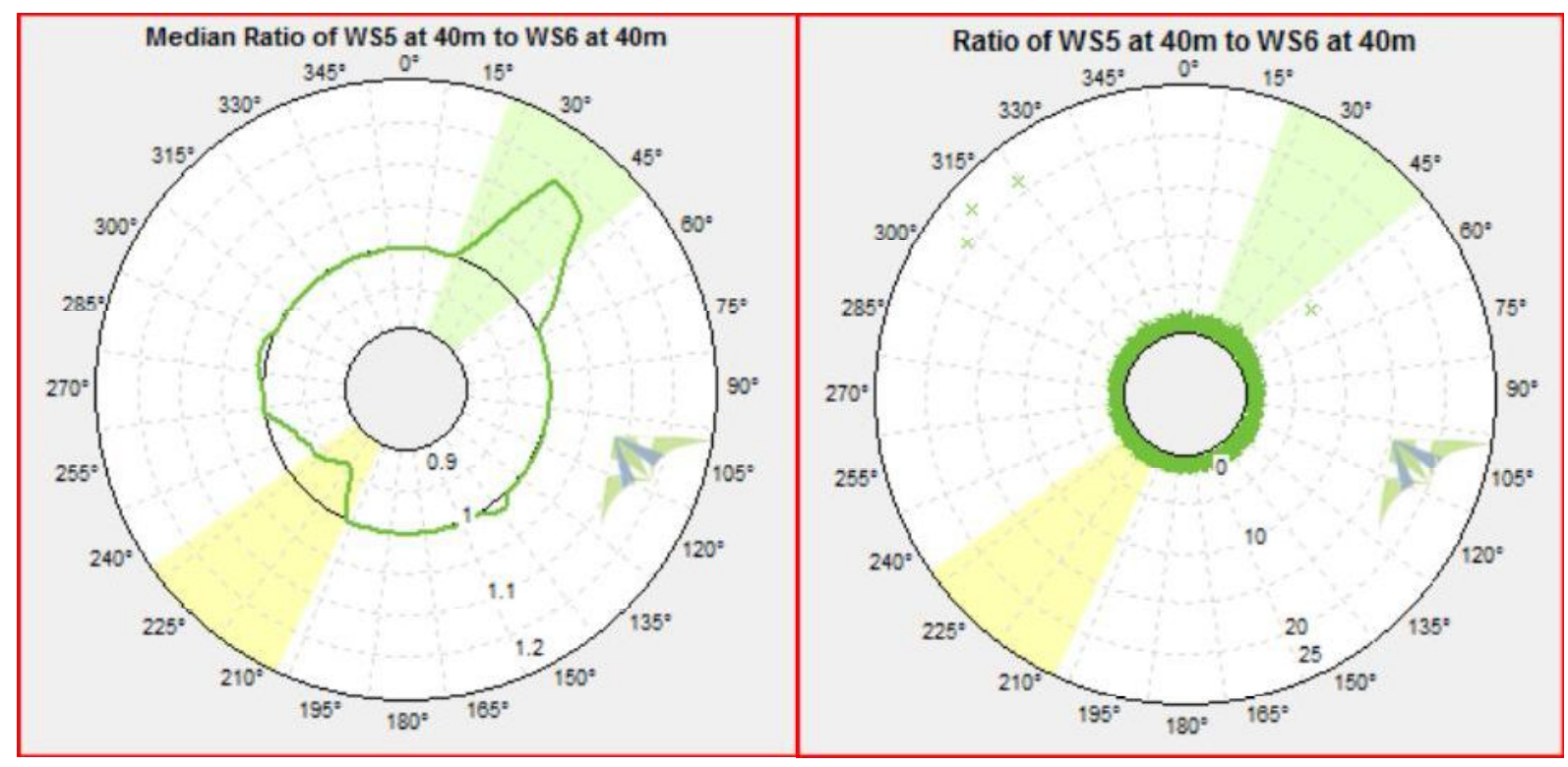

Fig. 5. Variation of wind speed ration WS5/WS6 with wind direction at 40m for entire data set

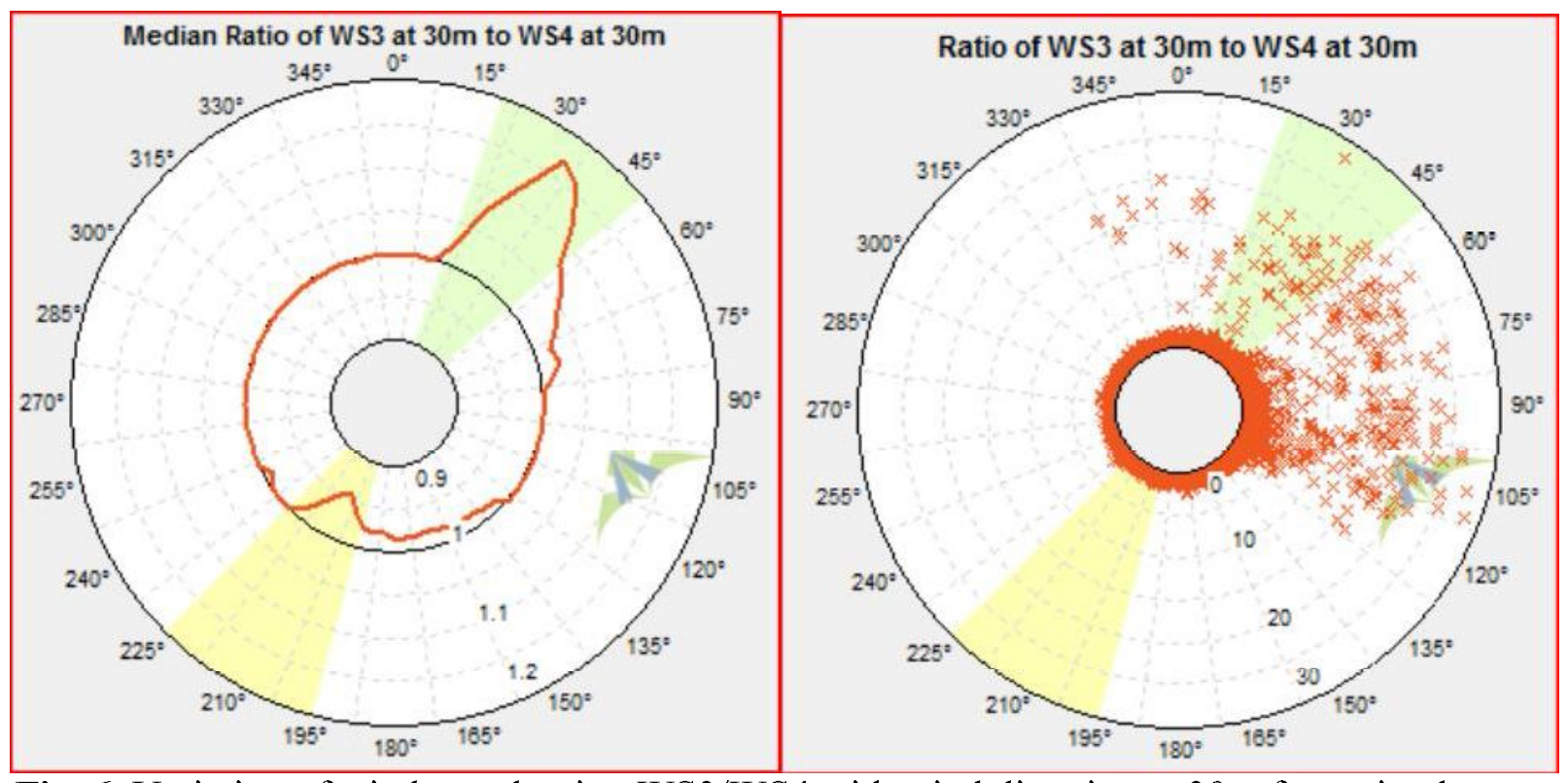

Fig. 6. Variation of wind speed ration WS3/WS4 with wind direction at 30m for entire data set 


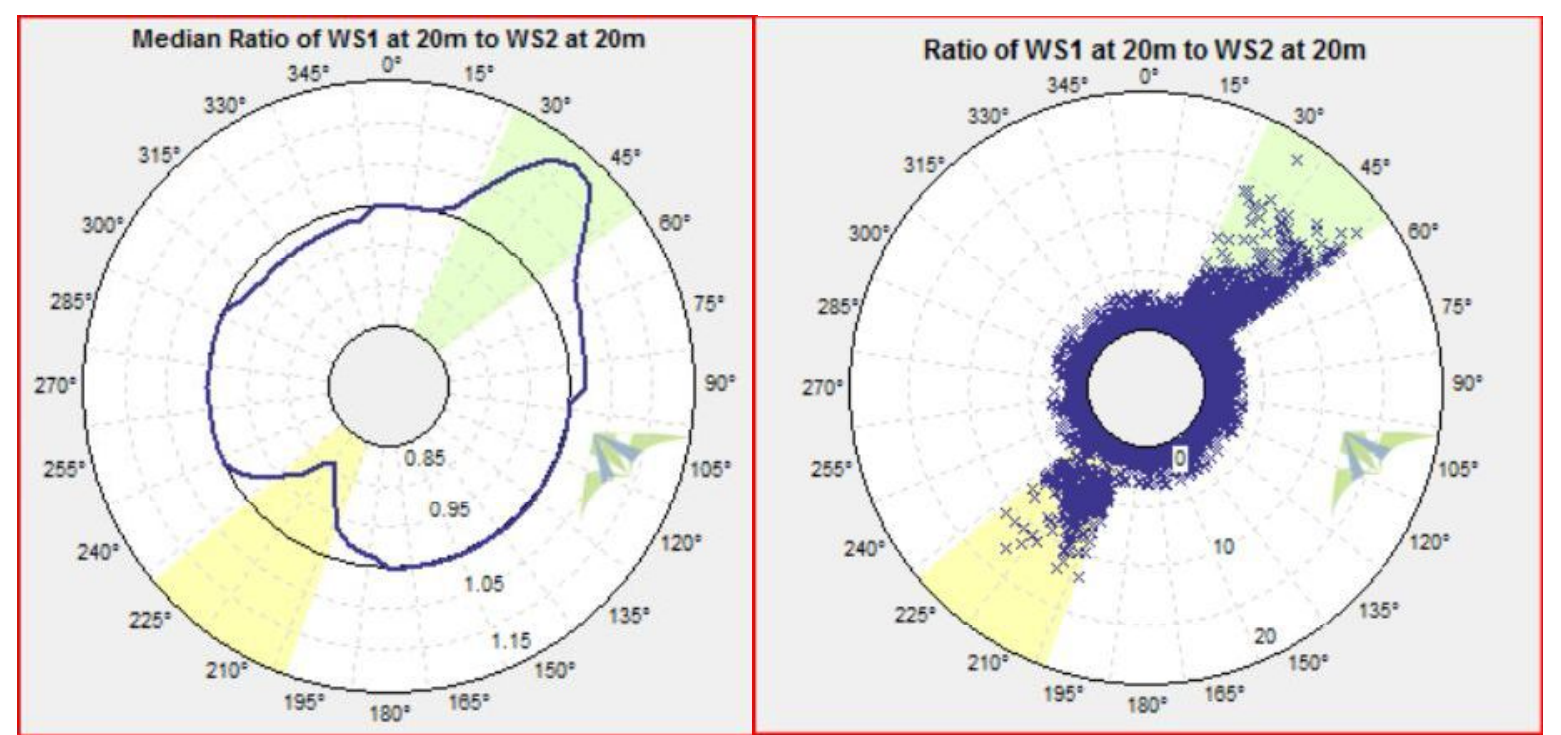

Fig. 7. Variation of wind speed ration WS1/WS2 with wind direction at 20m for entire data set

\section{Scatter Factor (SCF) Estimation}

The scatter factor (SCF) is a measure of spread in the ratio of the readings of pair of wind speed sensors. It is calculated as a weighted mean of the standard deviation of the ratios in each direction sector. The mean is weighted by the number of data points in each sector. The following equation defines the scatter factor [22]:

$$
S C F=\frac{\sum_{i=1}^{n} \sigma_{i} m_{i}}{\sum_{i=1}^{n} m_{i}}
$$

Where $\mathrm{n}$ is the number of direction sectors, $\sigma_{i}$ is the standard deviation of the ratios in direction sector $\mathrm{i}$, and $m_{i}$ is the number of records in direction sector $\mathrm{i}$. In the present case, the scatter factors are calculated using Eq. (2) for co-located anemometer at 20m (WS1/WS2), 30m (WS3/WS4) and 40m (WS5/WS6) heights and are summarized in Table 3. In this table, the SCF values are included for three data sets i.e. (i) entire data set which includes the invalid and the tower shading records, (ii) data set with invalid records but without tower shading records, and (iii) only valid records i.e. no invalid and tower shading records. The values of SCF in later two cases were found to be more or less the same, as can be observed from Table 3. 
It is obvious from Table 3 that SCF values were higher with tower shading effect compared to that without tower shading effect. It was further noticed that at $20 \mathrm{~m}$ the SCF values in the two cases i.e. with and without tower shading effect, though highest, but were close to each other compared to those at 40 and $30 \mathrm{~m}$. From these facts, it may be inferred that the tower shading effect is not the predominant factor near ground level instead the surface roughness plays a dominant role whereas scattering is concerned. In general, the annual mean values of SCF were found to be increasing from 2006 to 2009 with some exception where it was not true. For example, at 40m (second column) the SCF values increased from 2007 to 2009 but in 2006 it was much higher than that in 2007. The highest values of SCF were observed in the month of April at 40,30 and 20m heights while the minima were seen in July, Fig. 8. An increasing trend was noticed from January till April and then decreasing towards July and then again an uptrend till October and downtrend towards the end of the year.

Table 3

Scatter factors with and without tower shading at Rawdat Ben Habbas wind mast site.

\begin{tabular}{|c|c|c|c|c|c|c|c|c|c|c|c|}
\hline \multirow{3}{*}{ Year } & \multicolumn{9}{|c|}{ Tower Distortion Factor } & \multicolumn{2}{|c|}{ Records } \\
\hline & \multicolumn{3}{|c|}{$\begin{array}{c}\text { With Tower Shading } \\
\text { +Invalids }\end{array}$} & \multicolumn{3}{|c|}{$\begin{array}{c}\text { No Tower Shading } \\
\text { +Invalids }\end{array}$} & \multicolumn{3}{|c|}{$\begin{array}{c}\text { Only Valid Records } \\
\text { No Tower Shading + No } \\
\text { Invalids }\end{array}$} & \multicolumn{2}{|c|}{ Shading } \\
\hline & $40 \mathrm{~m}$ & $30 \mathrm{~m}$ & $20 \mathrm{~m}$ & $40 \mathrm{~m}$ & $30 \mathrm{~m}$ & $20 \mathrm{~m}$ & $40 \mathrm{~m}$ & $30 \mathrm{~m}$ & $20 \mathrm{~m}$ & Yes & No \\
\hline All & 0.139 & 0.923 & 1.574 & 0.065 & 0.096 & 1.634 & 0.065 & 0.096 & 0.100 & 244,709 & 213,250 \\
\hline 2006 & 0.203 & 0.051 & 0.065 & 0.052 & 0.047 & 0.058 & 0.052 & 0.047 & 0.058 & 52.559 & 45,817 \\
\hline 200 & 0.054 & & 1.079 & 0.043 & 0.1 & & 0.043 & 0.1 & 0.076 & & 46,147 \\
\hline 200 & 0.07 & & & 0.069 & & 0.8 & 0.069 & 0.1 & 0.089 & & 46,675 \\
\hline 2009 & 0.088 & 0.647 & 0.895 & 0.078 & 0.085 & 0.882 & 0.078 & 0.085 & 0.070 & 52.560 & 46,143 \\
\hline
\end{tabular}




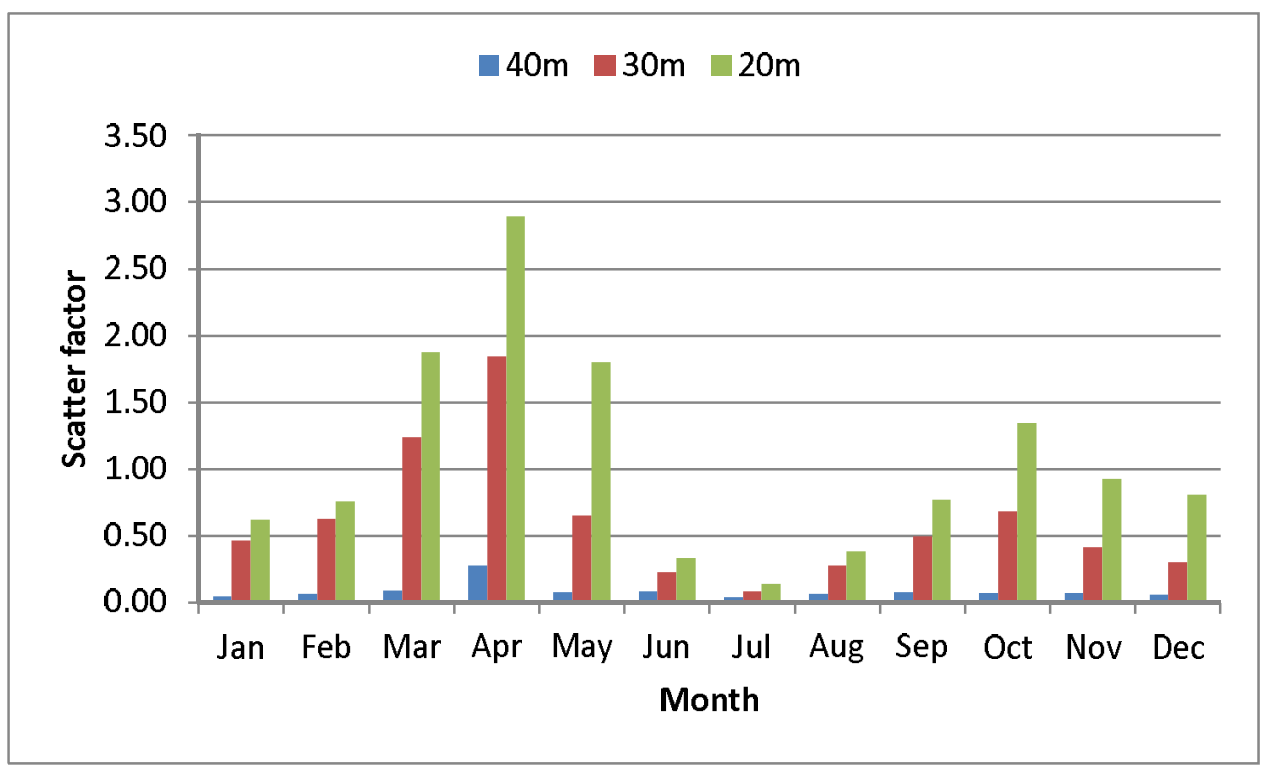

Fig. 8. Monthly variation of scatter factor at Rawdat Ben Habbas wind mast site

\section{Correlation Between Co-located wind Speed Sensors}

This section discusses the development of linear correaltions between co-located wind speed sensors at 20,30 and 40m heights with and without tower shading effects and with and without invalid data points. The scatter plot between wind speeds WS1 and WS2 for entire data set during $13^{\text {th }}$ September 2005 to $9^{\text {th }}$ May 2010 , including invalid and tower shading data points, is shown in Fig. 9(a). The best linear fit line $\left(\mathrm{R}^{2}=0.805\right)$ and the line passing through origin $\left(\mathrm{R}^{2}=0.767\right)$ are also included. In this case, the mean wind speeds WS1 and WS2 were 4.74 and $4.52 \mathrm{~m} / \mathrm{s}$ at $20 \mathrm{~m}$ AGL based on a total of 244,709 records. For no tower shading (NTS), the number of valid records were 214,586 and the mean wind speeds were 4.83 and $4.62 \mathrm{~m} / \mathrm{s}$, as given in Table 4. The corresponding scatter plot and the best fit lines with $\mathrm{R}^{2}$ of 0.769 and 0.806 are shown in Fig. 9(b). The mean wind speed values WS1 and WS2 increased by approximately $1.9 \%$ and $2.2 \%$ and best fit lines were seen to be improved slighly with a little higher avlues of $\mathrm{R}^{2}$. In the last case with valid records only (i.e. without tower shading effect and invalid records) the mean wind speed values changed silghly to 4.82 and $4.85 \mathrm{~m} / \mathrm{s}$ but the best fit line correlations improved a lot to 0.992, as shown in Fig. 9(c) and also given in Table 4. 
The correlations between wind speed sensors at 30 and $40 \mathrm{~m}$ without tower shading effects were always $99 \%$ as seen from Table 5 and 6 . The correlation coefficients for data set with tower shading effects were slighly less than those without tower shading, as can be observed from data given in Table 5. With tower shading effect, the correlation performance of the wind speed sensors at $30 \mathrm{~m}$ deteroriated by $1 \%$ while at $40 \mathrm{~m}$ by $3 \%$, as can be compared from data given in Tables 5 and 6 . At $30 \mathrm{~m}$ measurement height, with and without tower shading, the $\mathrm{R}^{2}$ values improved from 0.90 to 0.99 as can be seen from Table 5. At 40m, see Table 6, the effect of invalid records on mean wind speed values and the correlation between co-located wind speed sensors was negligible. Here it can be inferred that effect of tower shading on wind scattering decreases with increasing measurement heights.
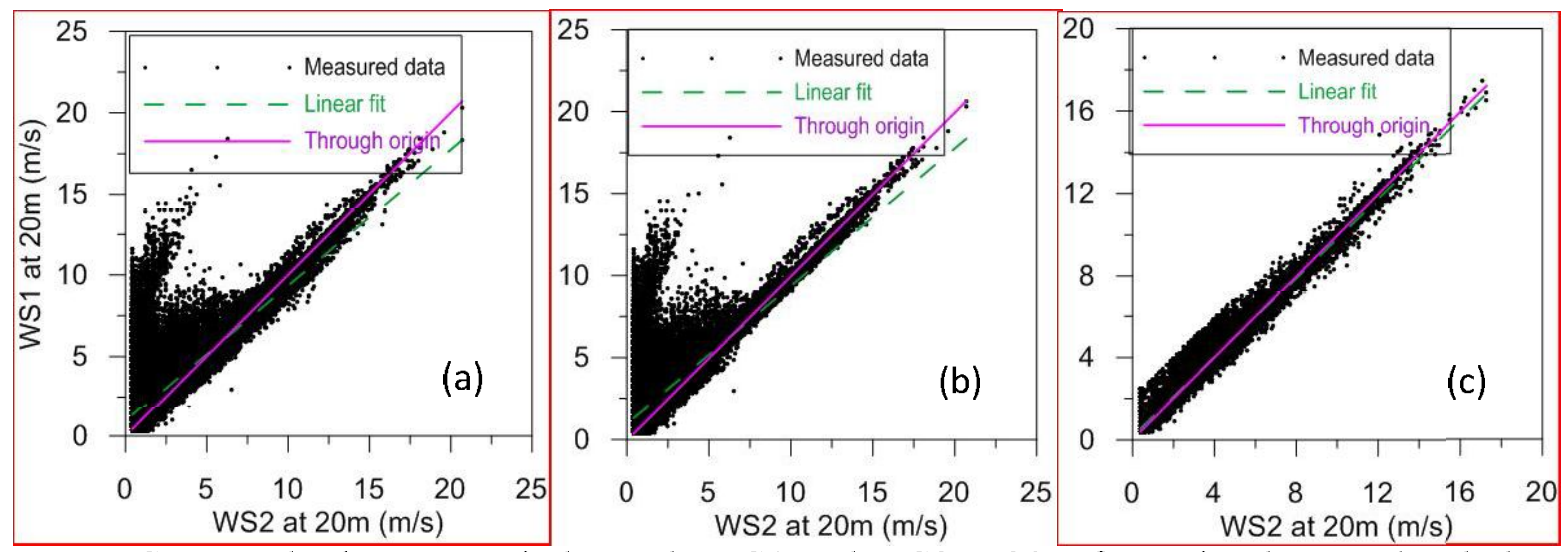

Fig. 9. Scatter plot between wind speeds WS1 and WS2 at $20 \mathrm{~m}$ for entire data set (excludes only tower shading points).

\section{Table 4}

Best fit equations and coefficient of performance for scatter plots at $20 \mathrm{~m}$ height.

\begin{tabular}{|c|c|c|c|c|c|}
\hline \multirow{2}{*}{$\begin{array}{l}\text { Data } \\
\text { points }\end{array}$} & \multicolumn{2}{|c|}{$\begin{array}{c}\text { Wind speed } \\
(\mathrm{m} / \mathrm{s})\end{array}$} & \multirow{2}{*}{ Correlation equation } & \multirow[t]{2}{*}{$\mathrm{R}^{2}$} & \multirow{2}{*}{ Comments } \\
\hline & WS1 & WS2 & & & \\
\hline 244,709 & 4.74 & 4.52 & $\begin{array}{l}\mathrm{WS} 1=1.0008 * \mathrm{WS} 2 \\
\mathrm{WS} 1=0.9450+0.8403 * \mathrm{WS} 2\end{array}$ & $\begin{array}{l}0.767 \\
0.805\end{array}$ & $\begin{array}{l}\text { Complete data set includes } \\
\text { invalid and tower shading }\end{array}$ \\
\hline 214,586 & 4.83 & 4.62 & $\begin{array}{l}\text { WS } 1=0.9989 * \mathrm{WS} 2 \\
\mathrm{WS} 1=0.9560+0.8389 * \mathrm{WS} 2\end{array}$ & $\begin{array}{l}0.769 \\
0.806\end{array}$ & No tower shading \\
\hline
\end{tabular}




$\begin{array}{llllll}202,024 & 4.82 & 4.85 & \text { WS1 }=0.9909 * \mathrm{WS} 2 & 0.992 & \begin{array}{l}\text { No tower shading and no } \\ \text { WS1 }=0.0499+0.9827 * \mathrm{WS} 2 \\ 0.992\end{array} \\ & & \end{array}$

\section{Table 5}

Best fit equations and coefficient of performance for scatter plots at $30 \mathrm{~m}$ height.

\begin{tabular}{|c|c|c|c|c|c|}
\hline \multirow{2}{*}{$\begin{array}{l}\text { Data } \\
\text { points }\end{array}$} & \multicolumn{2}{|c|}{$\begin{array}{l}\text { Wind speed } \\
(\mathrm{m} / \mathrm{s})\end{array}$} & \multirow{2}{*}{ Correlation equation } & \multirow[t]{2}{*}{$\mathrm{R}^{2}$} & \multirow{2}{*}{ Comments } \\
\hline & WS3 & WS4 & & & \\
\hline 244,709 & 5.34 & 5.21 & WS3 $=1.0043 *$ WS4 & $\begin{array}{l}0.900 \\
0.909\end{array}$ & Complete data set includes \\
\hline 206,611 & 5.40 & 5.39 & $\begin{array}{l}\text { WS } 3=0.9980 * \text { WS } 4 \\
\text { WS } 3=0.1231+0.9793 * \text { WS } 4\end{array}$ & $\begin{array}{l}0.992 \\
0.992\end{array}$ & No tower shading \\
\hline 195,824 & 5.39 & 5.38 & $\begin{array}{l}\text { WS3 }=0.9977 * \mathrm{WS} 4 \\
\text { WS } 3=0.1192+0.9796 * \mathrm{WS} 4\end{array}$ & $\begin{array}{l}0.992 \\
0.992\end{array}$ & $\begin{array}{l}\text { No tower shading and no } \\
\text { invalid data points }\end{array}$ \\
\hline
\end{tabular}

Table 6

Best fit equations and coefficient of performance for scatter plots at $40 \mathrm{~m}$ height.

\begin{tabular}{|c|c|c|c|c|c|}
\hline \multirow{2}{*}{$\begin{array}{l}\text { Data } \\
\text { points }\end{array}$} & \multicolumn{2}{|c|}{$\begin{array}{c}\text { Wind speed } \\
(\mathrm{m} / \mathrm{s})\end{array}$} & \multirow{2}{*}{ Correlation equation } & \multirow[t]{2}{*}{$\mathrm{R}^{2}$} & \multirow{2}{*}{ Comments } \\
\hline & WS5 & WS6 & & & \\
\hline 244,709 & 5.72 & 5.68 & $\begin{array}{l}\text { WS5 }=1.0037 * \text { WS } 6 \\
\text { WS5 }=0.1197+0.9863 * \text { WS6 }\end{array}$ & $\begin{array}{l}0.987 \\
0.987\end{array}$ & $\begin{array}{l}\text { Complete data set includes } \\
\text { invalid and tower shading }\end{array}$ \\
\hline 211,199 & 5.84 & 5.83 & $\begin{array}{l}\mathrm{WS} 5=1.0007 * \mathrm{WS} 6 \\
\mathrm{WS} 5=0.0305+0.9966 * \mathrm{WS} 6\end{array}$ & $\begin{array}{l}0.997 \\
0.997\end{array}$ & No tower shading \\
\hline 198,987 & 5.82 & 5.81 & $\begin{array}{l}\text { WS } 5=1.0009 * \text { WS } 6 \\
\text { WS } 5=0.0323+0.9965 * \text { WS6 } 6\end{array}$ & $\begin{array}{l}0.997 \\
0.997\end{array}$ & $\begin{array}{l}\text { No tower shading and no } \\
\text { invalid data points }\end{array}$ \\
\hline
\end{tabular}

\section{Turbulence Intensity (TI) Estimation}

The turbulence intensity is a dimensionless number defined as the standard deviation of the wind speed within a time step divided by the mean wind speed over that time step. It is a measure of the gustiness of a wind resource. Lower turbulence results in lower mechanical loads on a wind turbine and vice versa. The turbulence intensity is calculated for each time step (10 minutes in the present case) using the following equation [23-26]:

$T I=\sigma_{i} / v_{i}$ 
where $v_{i}$ is the average wind speed in time step $i$ and $\sigma_{i}$ is the standard deviation of the wind speed within time stem step $i$ (same unit as $v_{i}$ ).

The scatter plot of the TI versus wind speed showed that the highest TI corresponded to the lowest wind speed. The mean and representative TI values at $15 \mathrm{~m} / \mathrm{s}$ wind speed along with IEC3 turbulence category for entire data set and individual years are given in Table 7 station under study. This table also included the number of records for which the wind speed was $15 \mathrm{~m} / \mathrm{s}$. The annual mean values of TI at $15 \mathrm{~m} / \mathrm{s}$ wind speed at $20 \mathrm{~m}$ were 0.10 and 0.11 corresponding to wind speeds WS1 and WS2 while at 30m TI values were 0.10 corresponding to WS3 and WS4. At $40 \mathrm{~m}$ TI values were 0.10 and 0.09 corresponding to wind speed sensors WS5 and WS6. In all the cases, the mean TI values were smaller than the representative values of TI at $15 \mathrm{~m} / \mathrm{s}$. Raichle and Carson [23] reported annual average values of TI's below 0.17 at various sites in United States which shows that the present values of mean TI are compatible. Al-Yahyai et al. [24] analyzed the wind speed data measured at various locations in Oman and reported mean annual TI's between 0.41 and 0.90 which are much higher than the one found in the present case.

\section{Table 7}

Mean turbulence intensity at different heights

\begin{tabular}{|c|c|c|c|c|c|c|}
\hline Description & WS1 & WS2 & WS3 & WS4 & WS5 & WS6 \\
\hline $\begin{array}{l}\text { Records in } 15 \mathrm{~m} / \mathrm{s} \\
\text { bin }\end{array}$ & 107 & 117 & 200 & 229 & 300 & 322 \\
\hline Mean TI at $15 \mathrm{~m} / \mathrm{s}$ & 0.100 & 0.110 & 0.100 & 0.100 & 0.100 & 0.090 \\
\hline $\begin{array}{l}\text { Representative TI } \\
\text { at } 15 \mathrm{~m} / \mathrm{s}\end{array}$ & 0.140 & 0.150 & 0.0130 & 0.130 & 0.130 & 0.130 \\
\hline $\begin{array}{l}\text { IEC3 turbulence } \\
\text { category }\end{array}$ & $\mathrm{C}$ & $\mathrm{C}$ & $\mathrm{C}$ & $\mathrm{C}$ & $\mathrm{C}$ & $\mathrm{C}$ \\
\hline
\end{tabular}

The hourly and monthly mean values along with peak and representative values of TI at 20 , 30 , and $40 \mathrm{~m}$ above ground level are shown in Figs. 10 and 11, respectively. Well defined diurnal trends, with higher values between 1200 to 1700 hours, of mean and representative TI's 
were observed at all measurement heights. As expected, the peak values of TI are highest at all the measurement heights followed by representative values of TI and did not follow any definite diurnal trend. Moreover, the higher values of TI's were observed at lower heights compared to those at higher heights, as indicated in Figs. 10 and 11. The mean TI values were always $<0.25$ at $40 \mathrm{~m},<0.26$ at $30 \mathrm{~m}$, and $<0.28$ at $20 \mathrm{~m}$.

From monthly mean values of TI, it was noted that higher values of mean and representative Tl's were observed during April to May and August to September while smaller during rest of the months. The mean TI values were always $<0.16$ at $40 \mathrm{~m},<0.164$ at $30 \mathrm{~m}$, and $<0.185$ at $20 \mathrm{~m}$ above ground level, as can be seen from Fig. 11. At 40,30m and 20m AGL, the highest values of TI's of $0.16,0.164$ and 0.185 were found in the month of August, May and August, respectively. Al-Yahyai et al. [25] found minimum seasonal turbulence intensity of 0.33 at Qayroon Hyriti during summer and maximum seasonal intensity of 1.1 at Nizwa during winter. No definite seasonal trend was observed in the mean values of TI, see Fig. 11. Similar type of observations was reported by Raichle and Carson [23] for various locations in United States. It was also noted that mean TI values at $15 \mathrm{~m} / \mathrm{s}$ wind speed were always less than the reference and peak TI values at all the measurement heights and hence indicate no concerns for wind energy exploitation according to the 3rd edition of the IEC 61400-1. 


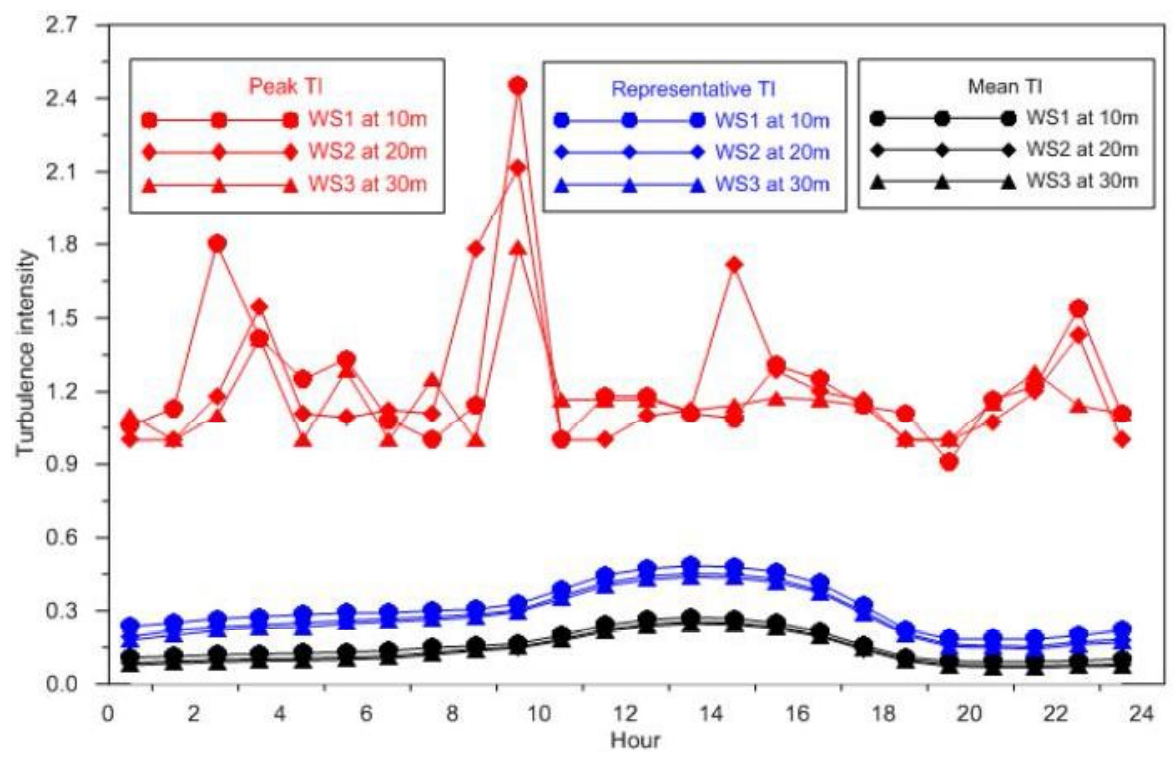

Fig. 10. Diurnal variation of turbulence intensity at different heights at Rawdat Ben Habbas meteorological station

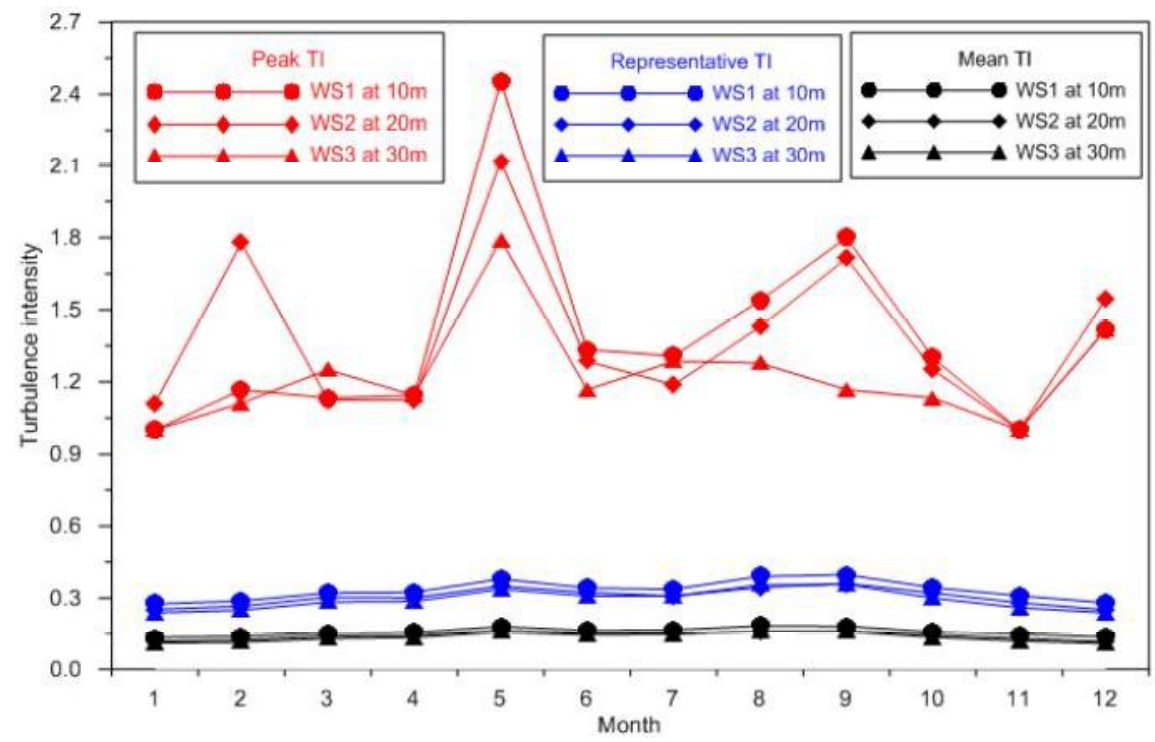

Fig. 11. Monthly variation of turbulence intensity at different heights at Rawdat Ben Habbas meteorological station

The variation of mean, representative, and peak TI values with mean wind speed is shown in

Fig. 12. It is evident from these values that mean TI's were always less than the peak and representative values. It is also obvious that higher values of TI's were found at lower mean wind speeds. In particular the mean TI values were always $<0.15$ at all measurement heights at 
wind speed $>4 \mathrm{~m} / \mathrm{s}$, as can be seen from Fig. 12. Moreover the TI values were found to be decreasing with increasing wind measurement height.

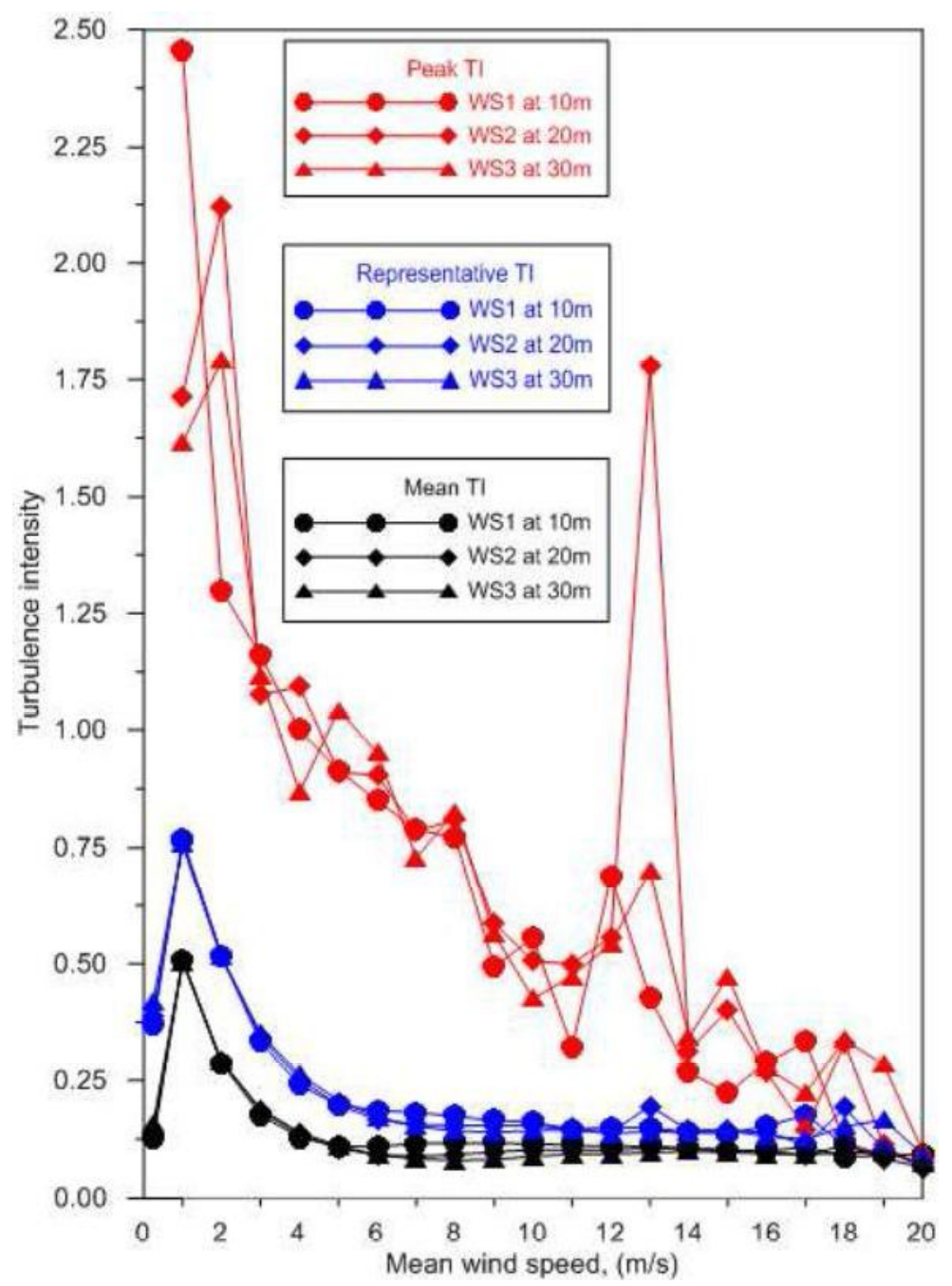

Fig. 12. Variation of turbulence intensity with wind speed at different heights at Rawdat Ben Habbas meteorological station

\section{Annual Energy and Plant Capacity Factor}

To comprehend an idea of annual energy yield, plant capacity factor, and compare the performance of 2MW rated power pitched controlled wind turbines at Rawdat Ben Habbas site, a total of 16 turbines (WT1 to WT16) from different manufacturers were selected. The cut-inspeed, rated-speed, and the rotor diameters of all the turbines are summarized in Table 8 . The wind turbine power curves and the measured wind speed were used to calculate the annual 
energy yield (AEY) and the net plant capacity factor (PCF) of each turbine. The AEY was calculated by taking in to consideration the effective losses of $13.2 \%$ consisting of different losses (availability losses $=2 \%$, wake effect losses $=4 \%$, turbine performance losses $=2 \%$, electrical losses $=2 \%$, environmental losses $=2 \%$, and other losses $=2 \%$ ).

The AEY and PCF values for all the selected wind turbines are compared in Figs. 13 and 14, respectively. Wind turbine (WT7) produced the maximum energy of 7000MWh with PCF of $40.2 \%$ followed by WT12, WT13, and WT14 which produced approximately 6000MWh of electricity each with respective PCF's of $34.57,34.47$, and $32.89 \%$. The performance of the wind turbine is also judged by two additional factors (i) percentage of time the wind turbine produced zero power ( $\mathrm{ZP})$ and (ii) percentage of time the wind turbine produced the rated power (RP) during the year. A wind turbine having minimum of the zero power and maximum of rated power is judged to be the better option in addition to the high PCF. The percentages of time of ZP and RP are compared in Fig. 15. The wind turbine WT7 with highest annual PCF and compatible values of $\mathrm{ZP}=8.55 \%$ and $\mathrm{RP}=6.69 \%$ was suggested as the best wind turbine. Most of the wind turbines were observed to produce zero power for more than $8 \%$ of time during the year and yet relatively less rated power, as can be seen from Fig. 15.

Table 8. Technical specifications of $2 \mathrm{MW}$ rated capacity pitch controlled wind turbines

\begin{tabular}{|c|r|r|r|}
\hline $\begin{array}{c}\text { Wind } \\
\text { turbine } \\
\text { types }\end{array}$ & $\begin{array}{c}\text { Cut-in- } \\
\text { speed } \\
(\mathrm{m} / \mathrm{s})\end{array}$ & $\begin{array}{c}\text { Rated- } \\
\text { speed } \\
(\mathrm{m} / \mathrm{s})\end{array}$ & $\begin{array}{c}\text { Rotor } \\
\text { diameter } \\
(\mathrm{m})\end{array}$ \\
\hline WT1 & 3.0 & 11.0 & 92.5 \\
\hline WT2 & 2.0 & 12.0 & 82.0 \\
\hline WT3 & 3.0 & 12.0 & 90.5 \\
\hline WT4 & 3.0 & 13.0 & 70.1 \\
\hline WT5 & 2.5 & 14.0 & 82.5 \\
\hline WT6 & 3.3 & 11.4 & 93.0 \\
\hline WT7 & 3.0 & 11.0 & 110.0 \\
\hline WT8 & 3.0 & 12.5 & 93.0 \\
\hline WT9 & 3.0 & 11.2 & 93.3 \\
\hline
\end{tabular}




\begin{tabular}{|c|r|r|r|}
\hline WT10 & 4.0 & 11.5 & 93.0 \\
\hline WT11 & 4.0 & 15.0 & 80.0 \\
\hline WT12 & 3.0 & 12.5 & 100.0 \\
\hline WT13 & 3.5 & 11.5 & 97.0 \\
\hline WT14 & 3.5 & 11.0 & 97.0 \\
\hline WT15 & 3.5 & 13.5 & 93.0 \\
\hline WT16 & 4.5 & 15.0 & 80.0 \\
\hline
\end{tabular}

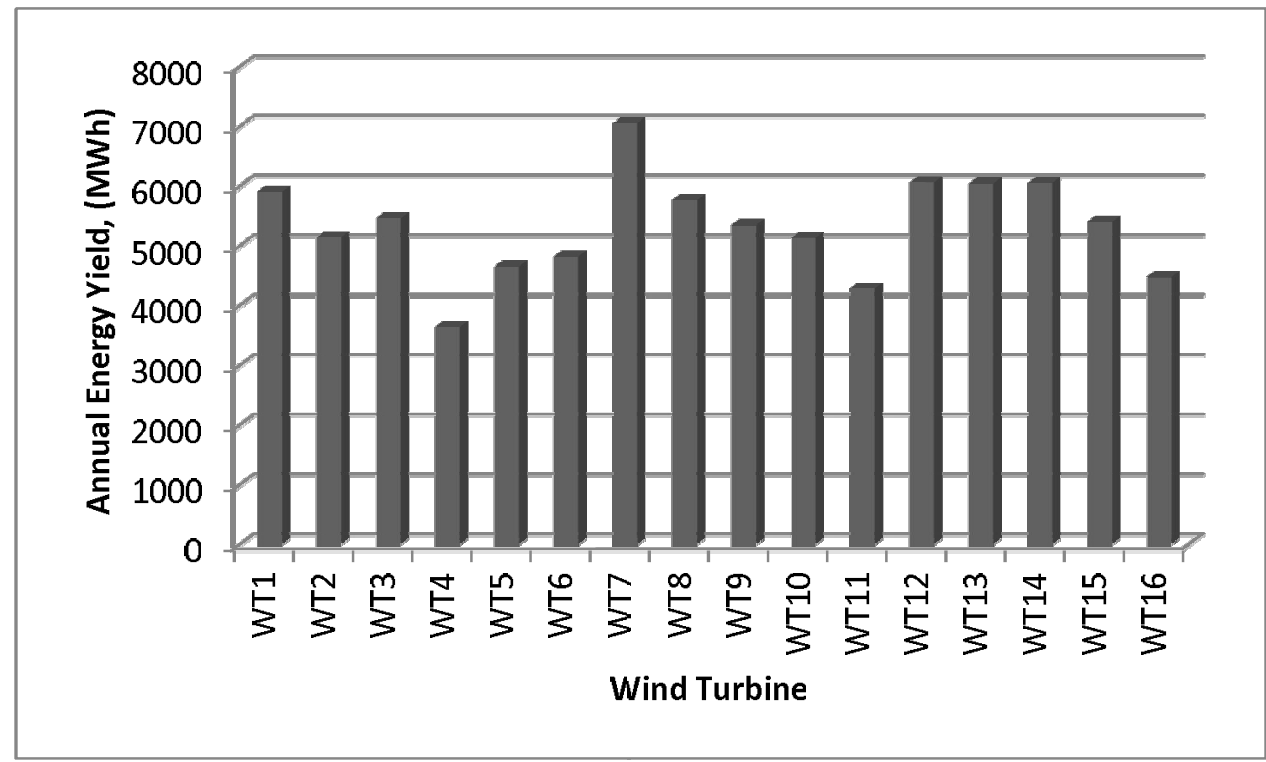

Fig. 13. Annual energy yield from different wind turbines at Rawdat Ben Habbas

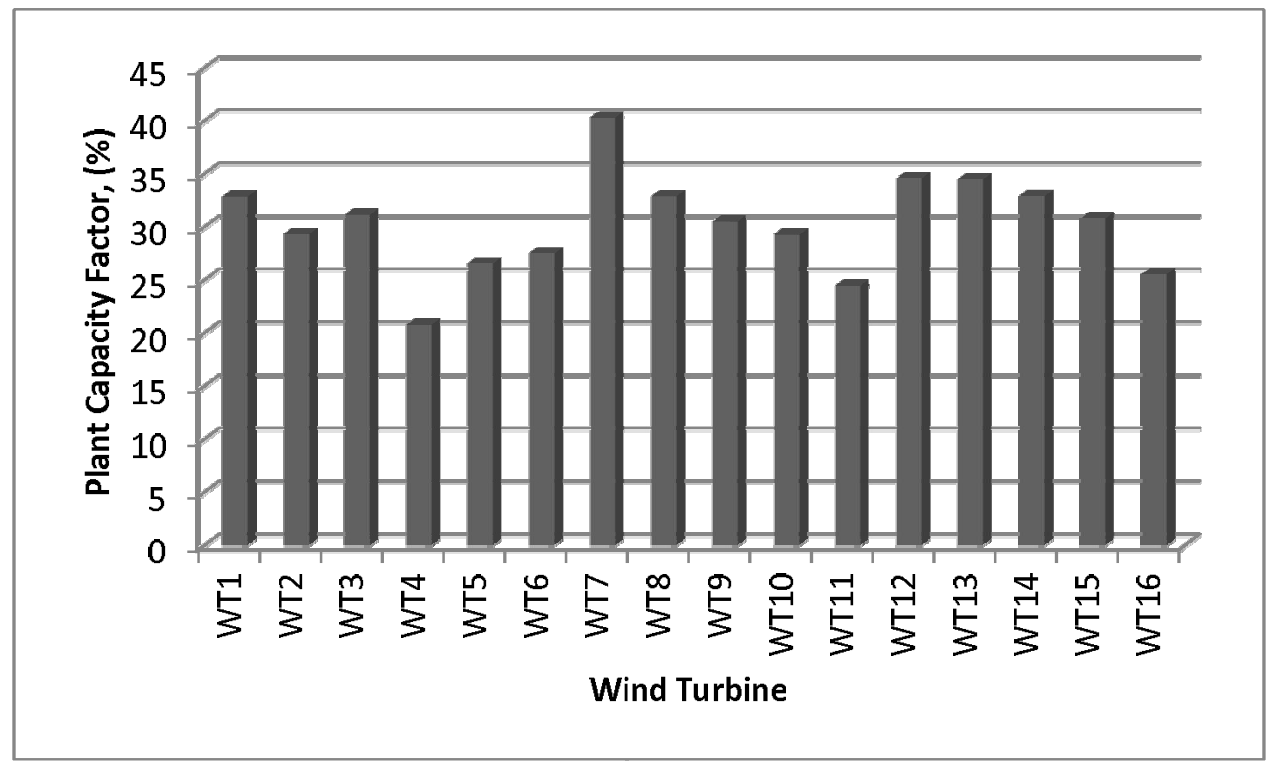

Fig. 14. Annual plant capacity factor of different wind turbines at Rawdat Ben Habbas 


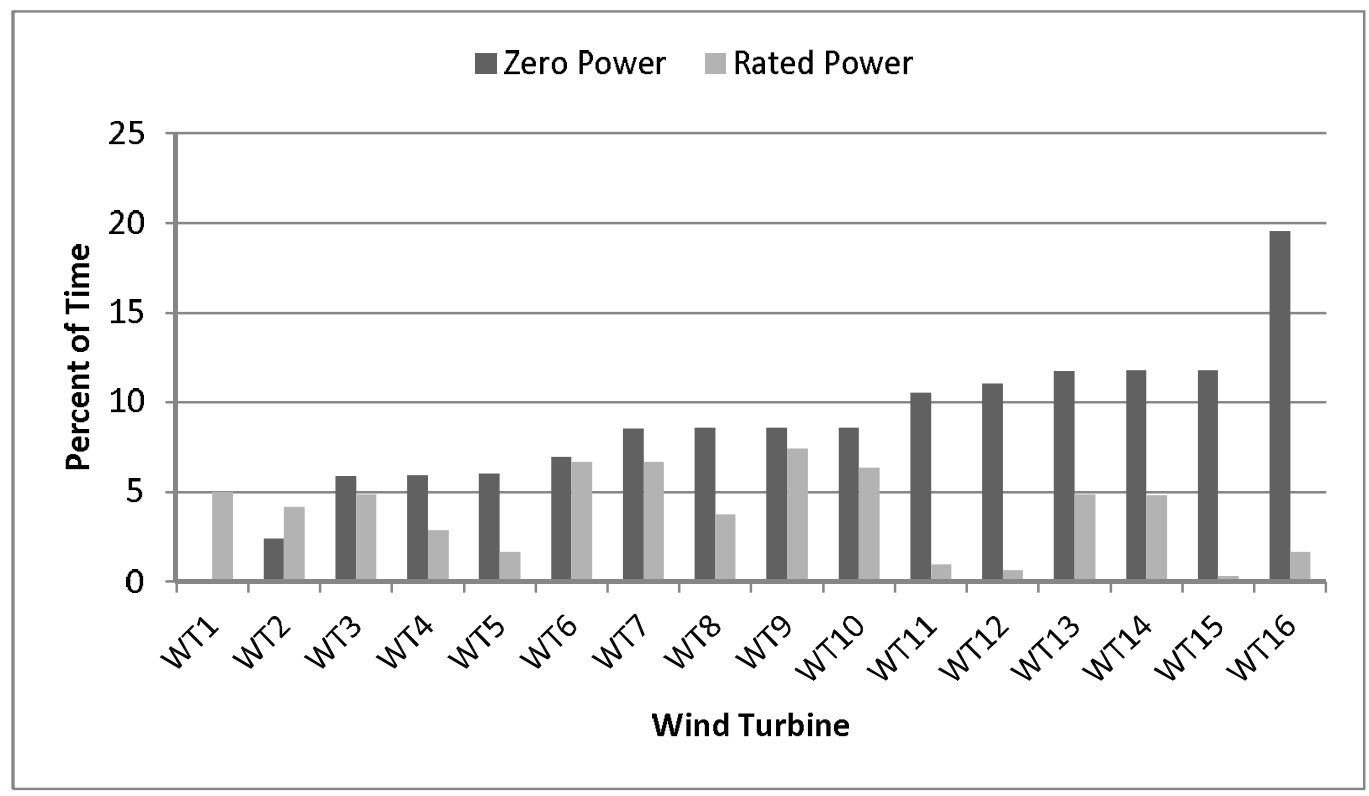

Fig. 15. Annual plant capacity factor of different wind turbines at Rawdat Ben Habbas

\section{Concluding Remarks}

The present work utilized hourly mean wind speed data measured at different heights at Rawdat Ben Habbas meteorological station in Saudi Arabia during September 13, 2005 and May 09, 2010 to study the performance of wind speed sensors with passage of time considering the tower distortion factor (TDF) and the scatter factor (SCF). The findings of the study could be summarized as follows:

- In general, higher values of TDF's were found at lower measurement heights and a decreasing trend was observed with increasing height. This was true for all the data sets considered in the present case i.e. data set with tower shading + invalid records, data set without tower shading + invalid records, and only valid records excluding the tower shading and the invalid records.

- The performance of wind anemometers at $20 \mathrm{~m}$ and $30 \mathrm{~m}$ height was affected more adversely as indicated by increasing TDF values with year and relatively higher magnitude compared to wind anemometers at $40 \mathrm{~m}$ height. This adverse effect on the wind anemometer 
performance at lower height may be accounted for by the presence of higher concentration of dust at $20 \mathrm{~m}$ and $30 \mathrm{~m}$ and higher surface roughness effects compared to that at $40 \mathrm{~m}$.

- In general, decreasing trends were observed in TDF and SCF values with increasing wind measurement height.

- An increasing trend was observed in the values of TDF from January till August and then decreasing towards the end of the year.

- From the results, it may be inferred that the tower shading effect is not the predominant factor near ground level instead the surface roughness plays a dominant role whereas scattering is concerned.

- Here it can be inferred that effect of tower shading on wind scattering decreases with increasing measurement heights.

- In general, the correlations between co-located wind speed sensors were excellent with $\mathrm{R}^{2}$ values of $>0.90$ without tower shading effect even better for data sets without tower shading and without invalid records. Better correlations were obtained at higher measurement heights compared to those at lower heights.

- The annual mean values of TI values at $15 \mathrm{~m} / \mathrm{s}$ wind speed were around 0.10 corresponding to wind speed measurements at all heights.

- Wind turbine WT7 with 7000MWh of annual energy yield and around 40\% PCF was found to be most suitable for the site under consideration for wind power development. The next bet group of turbines was WT12 to WT 14 with approximately $6000 \mathrm{MWh}$ of annual electricity production. 


\section{Acknowledgement}

The authors wish to acknowledge the support of the Research Institute of King Fahd University of Petroleum and Minerals, Dhahran, Saudi Arabia.

\section{References}

1. Global Wind Energy Council (GWEC) annual report - 2013- http://www.gwec.net/globalfigures/graphs/ (Accessed on April 13 2014)

2. Proposed Competitive Procurement Process for the Renewable Energy Program, Prepared $b y$ King Abdullah City for Atomic and Renewable Energy, 2013,www.kacare.gov.sa/cpp

3. Rehman S. Long-Term Wind Speed Analysis and Detection of its Trends Using MannKendall Test and Linear Regression Method. The Arabian Journal for science and Engineering 2013;38(2):421 - 437.

4. Rehman S, Halawnai TO, Mohandes M. Wind Power Cost Assessment at Twenty Locations in the Kingdom of Saudi Arabia. Renewable Energy 2003;28:573-583.

5. Rehman S, Mahbub AM, Meyer JP, Al-Hadhrami LM. Wind speed characteristics and resource assessment using Weibull parameters. International Journal of Green Energy 2012;9:800-814.

6. Rehman S, Aftab A, Al-Hadhrami LM. Development and economic assessment of a grid connected 20MW installed capacity wind farm. Renewable and Sustainable Energy Reviews 2011;15(1):833-838.

7. Fagbenle R.O., Katende J., Ajayi O.O., Okeniyi J.O., Assessment of wind energy potential of two sites in North-East, Nigeria, Renewable Energy, 36(4), (2011), 1277-1283.

8. McIntyre JH, Lubitz WD, Stiver W H. Local wind-energy potential for the city of Guelph, Ontario (Canada). Renewable Energy 2011;36(5):1437-1446.

9. Nor KM, Shaaban M, Abdul Rahman H. Feasibility assessment of wind energy resources in Malaysia based on NWP models. Renewable Energy 2014;62:147-154.

10. Katinas V, Sankauskas D, Markevičius A, Perednis E. Investigation of the wind energy characteristics and power generation in Lithuania. Renewable Energy 2014;66:299-304.

11. Nordman EE. Energy transitions in Kenya's tea sector: A wind energy assessment. Renewable Energy 2014;68:505-514.

12. Weekes SM, Tomlin AS. Comparison between the bivariate Weibull probability approach and linear regression for assessment of the long-term wind energy resource using MCP. Renewable Energy 2014;68:529-539.

13. Lindelöw-Marsden P, Pedersen TF, Gottschall J, Vesth A, Paulsen RWU, Courtney MS. Flow distortion on boom mounted cup anemometers. Ris $\varnothing-\mathrm{R}-1738(\mathrm{EN})$, August 2010.

14. IEC 61400-12-1. Wind turbines-Part 12-1: Power performance measurements of electricity producing wind turbines, 2005.

15. Filippelli M, Mackiewicz P. Experimental and computational investigation of flow distortion around a tubular meteorological mast. Proc. CanWEA Conference, 2005

16. Canadillas B, Westerhellweg A, Neumann T. Testing the performance of a ground-based wind LiDAR system-One year inter-comparison at the offshore platform Fino1. DEWI Magazine 2011;38:58-64. 
17. Canadillas B, Begue A, Neumann T. Comparison of turbulence spectra derived from LiDAR and sonic measurements at the offshore platform FINO1, 10th German Wind Energy Conference (DEWEK 2010), Bremen, Germany November 17-18, 2010.

18. Westerhellweg ., Canadillas B, Neumann T. Direction dependency of offshore turbulence intensity in the German Bight. DEWI Magazine 2011;38:66-70.

19. MOWE, 2008. Electricity Growth and Development in the Kingdom of Saudi Arabia $1428-$ $1429 \mathrm{H} / 2008 \mathrm{G}$, Ministry of Water and Electricity.

20. MOWE, 2011. Annual Report 1432 - 1433 H/2011G, Ministry of Water and Electricity (MOWE), Kingdom of Saudi Arabia.

21. Wind Energy Reference Manual at www.windpower.org (Accessed July 15, 2013)

22. Lambert T., Windographer Software Manual, http://www.windographer.com/

23. Raichle BW, Carson WR. Wind resource assessment of the Southern Appalachian Ridges in the Southeastern United States. Renewable and Sustainable Energy Reviews 2009;13:11041110.

24. Al-Yahyai S, Charabi Y, Gastli A, Al-Alawi S. Assessment of wind energy potential locations in Oman using data from existing weather stations. Renewable and Sustainable Energy Reviews 2010;14:1428-1436.

25. Dahmouni AW, Ben Salah MF, Kerkeni AC, Nasrallah SB. Wind energy in the Gulf of Tunis, Tunisia. Renewable and Sustainable Energy Reviews 2010;14:1303-1311.

26. Durisic Z, Mikulovic J. Assessment of the wind energy resource in the South Banat region, Serbia. Renewable and Sustainable Energy Reviews 2012;16:3014- 3023. 